\title{
ALAN R. BENDER
}

1944-2008

\author{
Dennis Todey \\ Agricultural and Biosystems Engineering \\ South Dakota State University \\ Brookings, SD
}

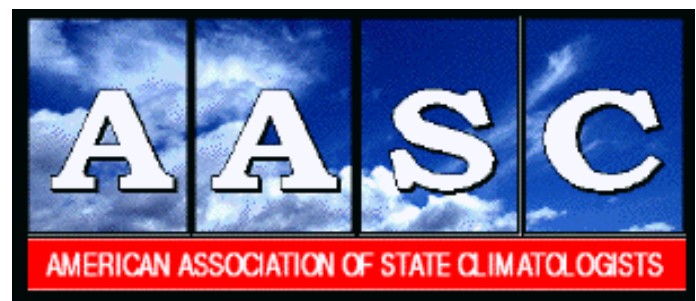

2008

Journal of Service Climatology

Volume 2, Number 5, Pages 1-2 


\title{
A Refereed Journal of the American Association of State Climatologists
}

\section{Alan R. Bender 1944-2008}

\author{
Dennis Todey \\ Agricultural and Biosystems Engineering \\ South Dakota State University \\ Brookings, SD
}

Corresponding author: Dennis Todey, State Climatologist, Agricultural and Biosystems Engineering, SAE 213 Box 2120, South Dakota State University; Brookings, SD 57007, USA. Tel.1-605-688-5678. Dennis.Todey@sdstate.edu.

Alan R. Bender, 63, of Volga, S.D., died suddenly in Brookings on Wednesday, Aug. 27, 2008. An open house visitation will be held 4-7 p.m. Friday, August 29, at Rude's Funeral Home, Brookings. Funeral services will be held at 11 a.m. on Saturday, August 30, at First Lutheran Church, Brookings.

"Big Al," as he was known to his friends and family, was a giant of a man with expansive intelligence, common sense, humor and an unrivaled dedication to family. He was an engineer, a climatologist, and a poet; a marathon runner, bicyclist and world traveler; a deep thinker, environmentalist and advocate for social and political change; an academic advisor and mentor to dozens of students and a friend to thousands. Most of all, he was a husband, father, wonderful grandfather, son, brother, cousin and uncle, and we all miss him.

Alan Reed Bender was a Christmas baby, born Dec. 25, 1944, to Edwin and Magdalene Bender in Mitchell, S.D. The middle of three sons, Alan grew up helping on the Bender farm near Fulton and playing with his brothers, Ron and Chuck.

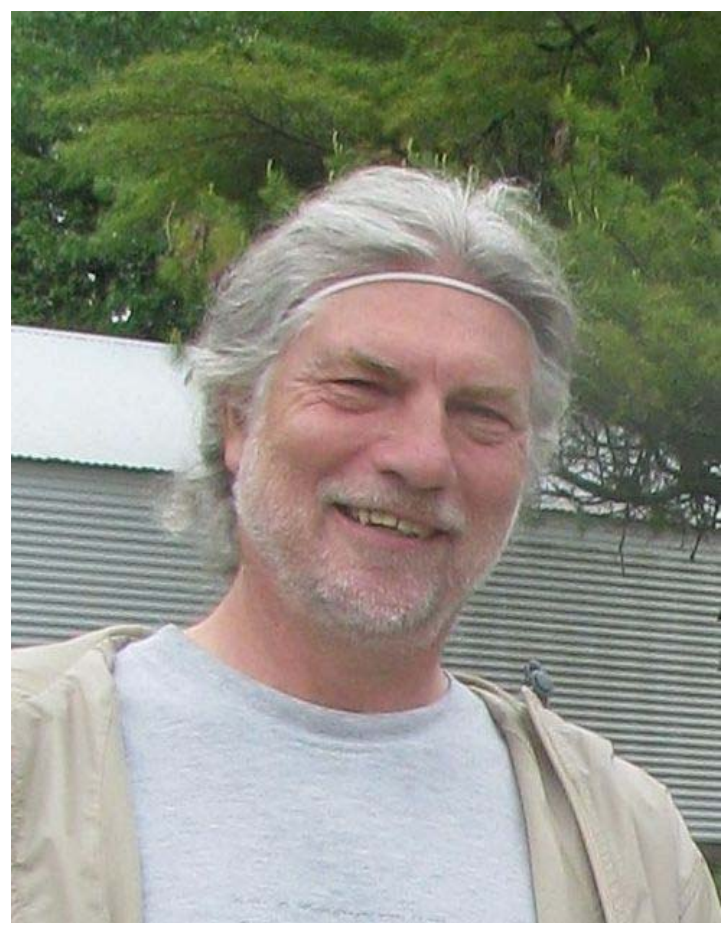

Inasmuch as he benefited from formal education during his life, $\mathrm{Al}$ also was self-taught in many disciplines. For example, he mastered calculus on his own at a young age. 
In 1962, Alan entered Augustana College, Sioux Falls. A year later, he transferred to South Dakota State University, a place where he would spend the majority of his professional life. Al graduated from SDSU in 1966 with a bachelor's degree in mathematics.

While at SDSU, Alan met Carol Bennett and they were married in Brookings on June 12, 1966. In 1967, Alan enlisted in the U.S. Air Force and was stationed at Forbes Air Force Base near Topeka, Kan., where he was a weather forecaster for the pilots serving in Vietnam. Following his discharge in 1971, Al and Carol moved back to South Dakota with their infant daughter, Cassondra, to Montrose, S.D., where they both taught school.

In 1976, to commemorate the Bicentennial, $\mathrm{Al}$ biked across the country, from South Dakota to Washington, D.C. He met many generous people and had many cool experiences along the way. In fact, he often remarked that people were so friendly that not once during the trip did he have to lock up his bike.

In 1979, he became an engineer and assistant professor of agricultural engineering at SDSU and the following year he completed his master's degree in agricultural engineering. In 1984 he was named acting director of the SDSU Water Resource Institute, a position he held until 1991. The previous year, he had been named an assistant professor and agricultural engineer in Extension and acting water quality coordinator. From 1991 to 2001 he was South Dakota's state climatologist.

His contributed significantly to the disciplinary knowledge base and helped pioneer many new processes through each of these positions; his professional achievements are too numerous to list.

Following his retirement in 2001, Alan turned his attention to poetry. He was invited to read his work at several public forums and his poems were published in numerous print and online publications. One of the highlights of his writing career was reading his poems at Shakespeare's Bookstore in Paris.

For many years, Alan was a leader of the MinnKota Region of the Church World Service and helped organize the local crop walk to alleviate world hunger. He also served on the board and taught confirmation at First Lutheran Church, Brookings. At the time of his death, Alan was a member of the committee organizing a sustainability conference for the McGovern Center for Leadership and Public Service Nov. 10-11, 2008 in Mitchell and was scheduled to lead a roundtable discussion titled "Hunger and Environmental Sustainability: Proposing Policy Solutions." He also was involved with Thunderhead Alliance, an organization that spearheaded the "Safe Routes to School" program in South Dakota. Al served on the committee that selected communities to receive funding for creating safe routes for children to walk and bike to school.

Alan is survived by his wife, Carol, Volga; daughter, Cassi (Martin) Fredricks, West Fargo, N.D.; three grandchildren, Saela, Martin and Mira; parents Ed and Mag Bender, Mitchell; brother Ron (Doris) Bender, Richfield, Minn.; brother Charles, Utah; and many beloved cousins, brothers- and sisters-in-law, nieces and nephews.

In lieu of flowers or gifts, the family requests donations be made to the Alan Bender Memorial Fund at First National Bank and Trust, Brookings. Funds will benefit a cause or organization dear to Alan's heart. E-mail condolences and greetings may be sent to the family through www.rudesfuneralhome.com. 